\title{
PENGARUH PENGGUNAAN SARI BUAH PEPAYA MUDA TERHADAP KEEMPUKAN, pH, DAN DAYA IKAT AIR DAGING ITIK PETELUR AFKIR
}

\author{
The Effect Unripe Papaya Extract on Tenderness, pH Value, and Water Holding Capacity of Laying \\ Duck Meat
}

Triyono, Rr Riyanti, dan Veronica Wanniatie

Departement of Animal Husbandry, Faculty of Agriculture, University of Lampung Jl. Prof. Dr. Soemantri Brojonegoro No.1 Gedung Meneng Bandar Lampung 35145 e-mail : triyonosantoso2505@gmail.com

\begin{abstract}
This research was aimed to determine the effect of unripe papaya extract on tenderness, $\mathrm{pH}$ value, and water holding capacity (WHC) of laying duck meat. This research was conducted in January 2020 in Laboratory of Animal Production of Animal Husbandary Department and in Laboratory of Agricultural Technology, Faculty of Agriculture, Lampung University. The materials of this research were 20 pieces of laying duck thigh meat. The research used Completely Randomized Design (CRD) with 4 treatments and 5 reaplications, i.e. duck thigh meat marination with $0 \%$ of unripe papaya extract (P0), with $10 \%$ of unripe papaya extract (P1), with $20 \%$ of unripe papaya extract (P2), and with $30 \%$ of unripe papaya extract (P3). The observed variables were tenderness, $\mathrm{pH}$ value, and WHC of laying duck meat. The obtained data was analyzed by using variance analysis at $5 \%$ level of significance, and if the results had significant effect, then were tested further using Least Significant Difference (LSD) test. The result of variance analysis indicated that marination of laying duck meat with different percentage of unripe papaya extract affected on tenderness $(\mathrm{P}<0,05)$, but it did not affect on $\mathrm{pH}$ value and WHC of laying duck meat.
\end{abstract}

Keywords: Laying duck meat, $\mathrm{pH}$ value, Tenderness, Unripe papaya extract, Water Holding Capacity (WHC)

\begin{abstract}
ABSTRAK
Penelitian ini bertujuan untuk mengetahui pengaruh penggunaan sari daging buah pepaya muda terhadap keempukan, nilai $\mathrm{pH}$, dan daya ikat air daging itik petelur afkir. Penelitian ini dilaksanakan pada Januari 2020 di Laboratorium Produksi Ternak, Jurusan Peternakan dan Laboratorium Instrumen Jurusan Teknologi Hasil Pertanian, Fakultas Pertanian, Universitas Lampung. Materi penelitian menggunakan 20 potong bagian paha itik petelur afkir. Penelitian ini menggunakan Rancangan Acak Lengkap (RAL) dengan 4 perlakuan dan 5 ulangan, yaitu marinasi daging paha dengan persentase sari buah pepaya muda sebanyak $0 \%(\mathrm{P} 0)$, marinasi daging paha dengan persentase sari buah pepaya muda sebanyak $10 \%(\mathrm{P} 1)$, marinasi daging paha dengan persentase sari buah pepaya muda sebanyak $20 \%(\mathrm{P} 2)$, marinasi daging paha dengan persentase sari buah pepaya muda sebanyak 30\% (P3). Peubah yang diamati adalah keempukan, nilai $\mathrm{pH}$, dan daya ikat air (DIA). Data yang diperoleh kemudian dianalisis ragam dengan taraf nyata 5\%, hasil yang berpengaruh nyata diuji lanjut menggunakan uji Beda Nyata Terkecil (BNT). Hasil analisis ragam menunjukkan bahwa marinasi dengan sari buah pepaya muda dengan persentase $0 \%$, $10 \%, 20 \%$, dan $30 \%$ memberikan pengaruh nyata $(\mathrm{P}<0,05)$ terhadap keempukan, tetapi tidak berpengaruh nyata terhadap nilai $\mathrm{pH}$ dan DIA daging itik petelur afkir.
\end{abstract}

Kata kunci: sari buah pepaya muda, keempukan, nilai $\mathrm{pH}$, daya ikat air, dan daging itik petelur afkir. 


\section{PENDAHULUAN}

Pemeliharaan ternak itik memiliki peran sebagai penunjang pendapatan petani peternak, baik sebagai usaha sampingan maupun usaha utama. Usaha ternak itik yang utama yaitu untuk diambil produksi telurnya dengan sistem penetasan, penyiapan bibit dan perbesaran calon petelur. Sayangnya untuk itik petelur afkir sendiri keberadaannya kurang diperhatikan.

Adanya fenomena peningkatan animo masyarakat untuk mengkonsumsi daging itik saat ini, dapat memberi dorongan positif bagi pengembangan potensi ternak itik baik dari segi kuantitas maupun kualitas. Hal ini juga ditunjang dengan kontribusi peran itik selama ini sebagai penghasil daging di Indonesia masih rendah. Badan Pusat Statistika (2019) melaporkan bahwa peran itik sebagai penghasil daging masih rendah, pada 2019 produksi itik sebesar 44.221 ton dengan kebutuhan konsumsi daging itik Nasional diestimasikan mencapai 75.000 ton. Dengan demikian, peningkatan produksi daging itik sangat diperlukan untuk menunjang kebutuhan konsumen akan produk tersebut.

Salah satu alternatif untuk memenuhi kebutuhan akan ketersediaan dan konsumsi daging, dapat dilakukan dengan memanfaatkan potensi daging itik petelur afkir. Masa pemeliharaan itik petelur dimulai dari fase starter, grower hingga layer, setelah itu itik sudah tidak produktif menghasilkan telur atau afkir (Maulana, 2013). Daging itik afkir dapat dimanfaatkan sebagai sumber protein dan lemak hewani, juga memiliki kandungan kalori relatif lebih rendah serta kandungan vitamin B lebih tinggi dibandingkan dengan daging unggas lainnya (Yuwono, 2012).

Daging itik petelur afkir memiliki nutrisi yang baik tetapi memiliki kelemahan pada segi kualitas fisiknya. Kelemahan daging itik afkir terutama dalam hal keempukan. Hal ini karena semakin tua umur ternak, maka jumlah jaringan ikat lebih banyak, sehingga meningkatkan kealotan daging (Fletcher, 2007). Pembatas ini mempengaruhi nilai harga jual daging itik (Bille dan Taapopi, 2008) karena konsumen menghendaki daging yang mempunyai mutu yang baik terutama dalam hal keempukan (Utami, et al., 2011).

Saat ini banyak metode yang dapat digunakan untuk melunakkan daging. Salah satunya yaitu dengan menggunakan bantuan enzim. Enzim papain telah banyak digunakan untuk meningkatkan keempukan daging terutama untuk ternak yang berumur tua, baik digunakan secara tradisional maupun dalam penelitian. Triyantini (1983), telah menggunakan enzim papain untuk melunakkan daging ayam tua dan tidak mempengaruhi kandungan kimiawinya baik air, protein dan lemak. Umumnya masyarakat di Indonesia menggunakan daun atau buah pepaya untuk melunakkan daging yang mereka olah.

Penggunaan enzim papain yang berasal dari tumbuhan pepaya khususnya yang menggunakan bagian daunnya sebagai penentu keempukan, nilai $\mathrm{pH}$, dan daya ikat air daging telah banyak diteliti, tetapi penggunaan daging buah pepaya sebagai penentu keempukan, nilai $\mathrm{pH}$, dan daya ikat air daging itik petelur afkir belum banyak diteliti. Tujuan penelitian ini yaitu untuk mengetahui pengaruh penggunaan sari buah pepaya muda terhadap keempukan, $\mathrm{pH}$, dan daya ikat air daging itik petelur afkir.

\section{MATERI DAN METODE}

\section{Waktu dan Tempat}

Penelitian ini dilaksanakan pada Januari 2020 di Laboratorium Produksi Ternak, Jurusan Peternakan dan Laboratorium Instrumen Jurusan Teknologi Hasil Pertanian, Fakultas Pertanian, Universitas Lampung.

\section{Bahan dan Alat}

Bahan yang digunakan pada penelitian ini yaitu sari buah pepaya muda yang berasal dari hasil penyaringan buah pepaya Jingga muda, aquades, dan daging itik petelur afkir jenis Hibrida bagian paha. Alat yang digunakan pada penelitian ini yaitu pisau stainless, nampan plastik ukuran $30 \times 20 \mathrm{~cm}$, timbangan analitik digital, kaca plat ukuran $25 \times 25 \mathrm{~cm}$, parutan, kain saring, talenan, baskom plastik ukuran 30x15 $\mathrm{cm}$, mortar alu, wadah plastik ukuran $10 \times 15 \mathrm{~cm}$, stopwatch, besi pemberat, label, alat tulis, texture analyzer, pH meter, dan kertas saring ukuran 5x5 $\mathrm{cm}$.

\section{Rancangan Percobaan}

Penelitian menggunakan metode

Rancangan Acak Lengkap (RAL) dengan 4 perlakuan dan 5 ulangan.

Perlakuan yang diberikan adalah:

P0: marinasi daging paha dengan persentase sari buah pepaya sebanyak $0 \%$ dari bobot sampel daging

P1: marinasi daging paha dengan persentase sari buah pepaya sebanyak $10 \%$ dari bobot sampel daging

P2: marinasi daging paha dengan persentase sari buah pepaya sebanyak $20 \%$ dari bobot sampel daging 
P3: marinasi daging paha dengan persentase sari buah pepaya sebanyak $30 \%$ dari bobot sampel daging.

\section{Pelaksanaan Penelitian}

Pelaksanaan penelitian ini diawali dengan pembuatan sari buah pepaya muda sesuai dengan komposisi yang diberikan. Daging itik yang digunakan yaitu bagian paha. Daging itik kemudian dimarinasi dengan sari buah pepaya muda sesuai perlakuan selama 30 menit kemudian ditiriskan dan diamati keempukan, $\mathrm{pH}$, dan daya ikat air.

\section{Peubah yang diamati}

Peubah yang diamati dalam penelitian ini adalah keempukan, $\mathrm{pH}$, dan daya ikat air daging itik petelur afkir. Langkah-langkah pengukuran keempukan daging dapat dilakukan dengan cara:

1. menyiapkan alat texture analyzer dengan merek Brook Field;

2. meletakkan daging dengan ukuran $(3 \times 3 \mathrm{~cm})$ dengan ketebalan $(2 \mathrm{~cm})$ tepat di bawah probe silinder;

3. mengaitkan jarum pada ujung sampel dengan posisi arah serat horizontal; dan

4. membaca hasil pengukuran yang angkanya tertera pada texture analyzer (Farida et al., 2006).

Langkah-langkah pengukuran $\mathrm{pH}$ daging dapat dilakukan dengan cara:

1. sebelum melakukan pengukuran, $\mathrm{pH}$ meter dikalibrasi;

2. membilas elektroda dengan aquades dan dikeringkan;

3. sampel daging yang telah diblender ditimbang seberat $10 \mathrm{~g}$ dan dicampur dengan $40 \mathrm{ml}$ aquades, kemudian dihomogenkan; dan

4. mencelupkan elektroda ke dalam sampel dan nilai $\mathrm{pH}$ dapat dibaca pada skala yang ditunjukkan oleh angka petunjuk (duplo).
Langkah-langkah pengukuran daya ikat air dapat dilakukan dengan cara:

1. menimbang sampel $0,28-0,32 \mathrm{~g}$ dengan memperhatikan arah serat;

2. menaruh sampel pada kertas saring berukuran $5 \times 5 \mathrm{~cm}$ diantara dua kaca datar $(25 \times 25 \mathrm{~cm})$;

3. menaruh pemberat seberat $10 \mathrm{~kg}$ di atas kaca dan biarkan selama 5 menit;

4. menimbang kembali sampel daging; dan

5. menghitung daya ikat air dengan rumus: $\% \mathrm{DIA}=100 \%-[(\mathrm{W} 0-\mathrm{W} 1) / \mathrm{W} 0) \mathrm{x}$ $100 \%$ ]

Keterangan : $\mathrm{W} 0=$ berat awal $\mathrm{W} 1$ = berat akhir

(Kissel et al., 2009).

\section{Analisis Data}

Data yang diperoleh dianalisis dengan analysis of variance (ANOVA) apabila hasil analisis berpengaruh nyata pada suatu peubah maka analisis dilanjutkan dengan uji beda nyata terkecil (BNT) pada taraf nyata 5\%.

\section{HASIL DAN PEMBAHASAN}

\section{Pengaruh Perlakuan terhadap Keempukan}

Rata-rata nilai keempukan dari hasil penelitian sebesar 62,16-114,00. Rata-rata nilai keempukan daging itik petelur afkir dengan perlakuan dan ulangan yang berbeda menggunakan sari buah pepaya muda dapat dilihat pada Tabel 1. Nilai rata-rata keempukan daging itik petelur afkir (Tabel 1), setelah dianalisis ragam hasilnya menunjukkan bahwa penggunaan sari buah pepaya muda berpengaruh nyata $(\mathrm{P}<0,05)$ terhadap peningkatan keempukan daging itik petelur afkir.

Tabel 1. Rata-rata nilai keempukan daging itik petelur afkir

\begin{tabular}{crrrc}
\hline \multirow{2}{*}{ Ulangan } & \multicolumn{4}{c}{ Perlakuan } \\
\cline { 2 - 4 } & \multicolumn{1}{c}{ P0 } & P1 & P2 & 73,80 \\
\hline 1 & 91,25 & 102,00 & 87,50 & 65,75 \\
2 & 131,00 & 65,24 & 100,75 & 47,50 \\
3 & 131,50 & 99,00 & 81,50 & 59,00 \\
4 & 107,75 & 72,50 & 67,00 & 64,75 \\
5 & 108,50 & 88,75 & 55,50 & $62,16^{\mathrm{a}}$ \\
\hline
\end{tabular}

Berdasarkan uji BNT pada taraf nyata $5 \%$, nilai keempukan terendah didapat pada perlakuan $0 \%$ yaitu marinasi daging paha dengan persentase sari buah pepaya sebanyak $0 \%$ dari bobot sampel daging. Semakin tinggi angka yang didapat dari pengukuran menggunakan texture 
analyzer maka makin rendah nilai keempukannya. Hal ini menunjukkan bahwa daging yang tidak dimarinasi sari buah pepaya muda memberikan keempukan daging yang rendah. Hal ini diduga karena tidak adanya peristiwa osmosis antara sari buah pepaya muda dengan air daging. Menurut Kuntoro et al. (2007), osmosis merupakan pertukaran air antara sel dengan lingkungan karena perbedaan konsentrasi. Hal ini berbanding terbalik dengan perlakuan $10 \%$, 20\%, dan $30 \%$ penambahan sari buah pepaya muda pada daging yang dalam hal ini terjadi proses osmosis antara sari buah pepaya muda dengan air daging yang menyebabkan senyawa aktif dalam sari bauh pepaya muda dapat terpenetrasi kedalam daging sehingga dapat memengaruhi terjadinya pemecahan protein daging yang berimbas pada peningkatan nilai keempukan daging itik petelur afkir.

Marinasi daging paha dengan persentase sari buah pepaya sebanyak $10 \%$ dan $20 \%$ memberikan pengaruh yang relarif sama terhadap keempukan (Tabel 1). Hal ini terjadi kemungkinan karena mekanisme kerja enzim papain pada $10 \%$ dan $20 \%$ penambahan sari buah pepaya muda relatif sama $(78,5$ pada $20 \%$ dan 85,5 pada $10 \%$ ). Jika dibandingkan dengan $0 \%$, perlakuan $10 \%$ dan $20 \%$ memiliki nilai keempukan lebih baik. Adanya peningkatan nilai keempukan pada perlakuan $10 \%$ dan $20 \%$ jika dibandingkan dengan perlakuan $0 \%$ terjadi karena adanya aktifitas enzim papain dalam sari buah pepaya muda yang membuat daging menjadi lebih empuk dengan memanfaatkan kemampuan enzim papain yang dapat bekerja menghidrolisis ikatan peptida pada protein daging. Dan jika $10 \%$ dan $20 \%$ dibandingkan dengan $30 \%$ hasilnya terlihat bahwa $30 \%$ memiliki nilai keempukan yang lebih baik. Menurut Lehninger (1994), enzim papain mempunyai kemampuan untuk melunakkan daging dan menghidrolisis ikatan peptida dari protein. Tingginya konsentrasi enzim yang digunakan akan memengaruhi banyaknya substrat yang dapat ditransformasi. Konsentrasi enzim yang berlebihan akan menyebabkan proses tersebut menjadi tidak efisien. Derajat kemurnian enzim papain yang tinggi, mempunyai hubungan linear dengan jumlah enzim dan taraf aktifitas.

Marinasi daging paha dengan komposisi sari buah pepaya sebanyak $30 \%$ menjadi sampel dengan nilai keempukan terbaik dibandingkan dengan $0 \%, 10 \%$, dan $20 \%$. Hal ini diduga karena kandungan papain di dalam sari buah pepaya muda yang memiliki kemampuan untuk menghidrolisis protein tepatnya menyerang endomisium yang menyelubungi serabut-serabut daging dan menghancurkan tenunan pengikat menjadi serabut, berdasarkan data pada (Tabel 1) terlihat bahwa 30\% memiliki angka yang paling rendah diantara perlakuan yang lain $0 \%, 10 \%$, dan $20 \%$, ini menandakan bahwa semakin banyak jumlah sari buah pepaya yang digunakan dalam perlakuan maka nilai keempukannya akan semakin meningkat atau dalam kata lain daging akan menjadi lebih empuk. Hal ini didukung oleh pendapat Farid (2015), papain memengaruhi serabut otot (enzim papain merupakan enzim protease yang berperan dalam menghidrolisis protein sehingga digunakan sebagai pengempuk daging). Pendapat pendukung lain diungkapkan oleh Sunarlim dan Usmiati (2009), proses pengempukan secara alamiah terjadi karena pemecahan protein-protein daging oleh enzim protease. Tampak bahwa penggunaan enzim papain membantu dalam proses pemecahan protein-protein daging yang semakin banyak. Peningkatan nilai keempukan daging disebabkan oleh adanya aktifitas enzim proteolitik atau protease yang memiliki kemampuan dalam memecahkan endomisium yang menyelubungi serabut-serabut daging dan menghancurkan tenunan pengikat menjadi serabut amorf. Diduga penyayatan sebelum marinasi dan dengan perlahan menekan-nekan daging saat proses marinasi dapat meningkatkan jumlah kandungan aktif di dalam sari buah pepaya muda khususnya enzim papain yang dapat terpenetrasi masuk kedalam serat-serat daging dan pada akhirnya dapat memengaruhi nilai keempukannya.

\section{Pengaruh Perlakuan terhadap Nilai pH Daging}

Rata-rata nilai $\mathrm{pH}$ dari hasil penelitian sebesar 6,38-6,64. Rata-rata nilai $\mathrm{pH}$ daging itik petelur afkir dengan perlakuan dan ulangan yang berbeda menggunakan sari buah pepaya muda dapat dilihat pada Tabel 2. Hasil analisis ragam menunjukkan bahwa penambahan sari buah pepaya muda memberikan pengaruh yang tidak nyata $(\mathrm{P}>0,05)$ terhadap nilai $\mathrm{pH}$ daging itik petelur afkir. Hal tersebut diduga karena adanya peristiwa osmosis yang kurang maksimal antara sari buah pepaya dengan air daging itik yang mengakibatkan kecilnya gerakan pada pertukaran air antara sel. Osmosis sendiri merupakan pertukaran air antara sel dengan lingkungan karena perbedaan konsentrasi (Kuntoro et al., 2007). Konsentrasi pada sari buah pepaya yang dianggap sama dengan konsentrasi air dalam daging mengakibatkan kurangnya pergerakan antar molekul yang menyebabkan zat aktif dalam buah pepaya tidak masuk secara optimal ke dalam daging dan 
menyebabkan kecilnya pengaruh terhadap $\mathrm{pH}$ daging itik petelur afkir.

Tabel 2. Rata-rata nilai $\mathrm{pH}$ daging itik petelur afkir

\begin{tabular}{ccccc}
\hline \multirow{2}{*}{ Ulangan } & \multicolumn{3}{c}{ Perlakuan } \\
\cline { 2 - 5 } & P0 & P1 & P2 & P3 \\
\hline 1 & 6,615 & 6,508 & 6,350 & 6,248 \\
2 & 6,616 & 6,556 & 6,334 & 7,012 \\
3 & 6,649 & 6,386 & 6,418 & 6,668 \\
4 & 6,289 & 6,495 & 6,545 & 6,319 \\
5 & 6,219 & 6,180 & 6,274 & 6,985 \\
\hline Rata-rata & 6,4776 & 6,425 & 6,3842 & 6,6464 \\
\hline
\end{tabular}

Kemungkinan lain yang menyebabkan $\mathrm{pH}$ daging itik petelur afkir tidak berpengaruh nyata $(\mathrm{P}>0,05)$ setelah dilakukannya perlakuan yaitu karena $\mathrm{pH}$ yang terkandung pada sari buah pepaya muda tidak dapat memengaruhi $\mathrm{pH}$ pada daging itik, dikarenakan $\mathrm{pH}$ sari buah pepaya muda yang relatif sama sekitar 5,96 dengan $\mathrm{pH}$ daging itik sebelum marinasi sekitar 6,47 (Tabel 2). Hasil ini sesuai dengan penelitian Ismanto dan Basuki (2017), bahwa hasil pengujian pH pada daging ayam yang ditambahkan EBP (ekstrak buah papaya) menunjukkan perbedaan yang tidak nyata.

Nilai $\mathrm{pH}$ terendah atau bisa dikatakan $\mathrm{pH}$ terbaik dari keseluruhan perlakuan yaitu terlihat pada $20 \%$ yaitu marinasi daging paha dengan persentase sari buah pepaya sebanyak $20 \%$ dari bobot sampel daging dengan nilai $\mathrm{pH} 6,38$, walaupun nilainya paling rendah dari seluruh perlakuan tetapi hasil ini tidak terlalu berbeda dengan perlakuan lain, khususnya jika dibandingkan dengan $0 \%(6,47)$ dan $10 \%(6,42)$, tetapi nilai $\mathrm{pH}$ sedikit terlihat berbeda pada $30 \%$ $(6,64)$, nilai $30 \%$ memperlihatkan $\mathrm{pH}$ tertinggi dari seluruh perlakuan. Hal tersebut diatas terjadi akibat nilai $\mathrm{pH}$ sari buah pepaya relatif sama sekitar 5,96 dengan $\mathrm{pH}$ daging perlakuan tanpa marinasi $(0 \%)$ sekitar 6,47 , sehingga pemberian larutan sari buah pepaya muda sebagai marinade daging itik petelur afkir tidak memengaruhi nilai $\mathrm{pH}$. Hal tersebut sesuai dengan penelitian Atmojo et al. (2016), pemberian larutan ekstrak lengkuas merah sebagai perendam daging ayam tidak memberi pengaruh yang nyata terhadap $\mathrm{pH}$ daging. $\mathrm{Hal}$ ini disebabkan oleh lengkuas merah memiliki pH 6,28 mendekati $\mathrm{pH}$ netral, sehingga pemberian larutan ekstrak lengkuas merah sebagai perendam daging ayam tidak memengaruhi nilai $\mathrm{pH}$. Daging yang direndam masih pada kisaran normal $\mathrm{pH}$ daging yaitu $5,63-5,80$.
Nilai $\mathrm{pH}$ daging yang dianjurkan Standar Nasional Indonesia yaitu 5,3--6,5. Berdasarkan penelitian yang dilakukan dengan menggunakan 20 sampel, terlihat bahwa 11 sampel memiliki nilai pH yang berada pada kisaran 6,18--6,49 (Tabel 2), sehingga masih menunjukkan batas yang dianjurkan karena masih berada pada kisaran Standar Nasional Indonesia. Nilai $\mathrm{pH}$ pada 9 sampel yang lain berada di atas Standar Nasional Indonesia yaitu berada pada kisaran angka 6,507,01 (Tabel 2), hal ini kemungkinan terjadi karena daging yang digunakan memang sudah memiliki $\mathrm{pH}$ yang tinggi dari awal sebelum perlakuan dan setelah dilakukan perendamanpun tidak terjadi penurunan $\mathrm{pH}$. Akibatnya nilai $\mathrm{pH} 9$ sampel tersebut terlihat lebih tinggi dibandingkan dengan 11 sampel lainnya. Pendapat lain menyatakan bahwa daging itik memiliki $\mathrm{pH}$ yang memang sudah tinggi dari waktu awal pasca pemotongan. Menurut Lukman (1995), daging dada dan paha itik nilai $\mathrm{pH}$ nyata lebih tinggi dibandingkan dengan daging ayam, masing-masing sebesar 6,12 dan 7,71 pada itik, 5,22 dan 5,74 pada ayam.

\section{Pengaruh Perlakuan terhadap Daya Ikat Air (DIA) \\ Rata-rata nilai DIA dari hasil penelitian} sebesar 61,28 - 66,61. Rata-rata nilai daya ikat air daging itik petelur afkir dengan perlakuan dan ulangan yang berbeda menggunakan sari buah pepaya muda dapat dilihat pada Tabel 3. Hasil analisis ragam menunjukkan bahwa penggunaan sari buah pepaya muda tidak berpengaruh nyata $(\mathrm{P}>0,05)$ terhadap DIA daging paha itik petelur afkir. Hal ini diduga disebabkan oleh nilai $\mathrm{pH}$ daging itik yang tidak berbeda nyata pada semua perlakuan dan cenderung tinggi. Tingginya $\mathrm{pH}$ daging diduga dapat menyebabkan DIA menjadi tinggi. Hal tersebut sesuai dengan pendapat 
Tabel 3. Rata-rata nilai DIA daging itik petelur afkir

\begin{tabular}{|c|c|c|c|c|}
\hline \multirow{2}{*}{ Ulangan } & \multicolumn{4}{|c|}{ Perlakuan } \\
\hline & P0 & P1 & $\mathrm{P} 2$ & P3 \\
\hline 1 & 67,741 & 64,516 & 71,875 & 60,000 \\
\hline 2 & 56,666 & 59,375 & 65,625 & 71,875 \\
\hline 3 & 63,333 & 58,620 & 79,310 & 59,375 \\
\hline 4 & 64,516 & 64,516 & 56,250 & 66,625 \\
\hline 5 & 62,500 & 59,375 & 60,000 & 61,290 \\
\hline Rata-rata & 62,9512 & 61,2804 & 66,612 & 63,833 \\
\hline
\end{tabular}

Keterangan: P0: marinasi daging paha dengan persentase sari buah pepaya muda sebanyak $0 \%$

P1: marinasi daging paha dengan persentase sari buah pepaya muda sebanyak $10 \%$

P2: marinasi daging paha dengan persentase sari buah pepaya muda sebanyak $20 \%$

P3: marinasi daging paha dengan persentase sari buah pepaya muda sebanyak $30 \%$

Pearson dan Young (1989) bahwa daya ikat air akan meningkat jika nilai $\mathrm{pH}$ daging meningkat. Menurut Allen, et.al. (1998), daya ikat air mempunyai hubungan positif dengan nilai $\mathrm{pH}$ daging. Menurut Soeparno (2009), pada pH yang lebih tinggi atau lebih rendah dari titik isoelektrik protein-protein daging, DIA meningkat, karena pada $\mathrm{pH}$ yang lebih rendah dari titik isoelektrik protein-protein daging, terdapat muatan positif yang mengakibatkan penolakan miofilamen dan memberi lebih banyak ruang untuk molekul-molekul air.

Hasil yang tidak berbeda nyata antar perlakuan ini serupa dengan penelitian Ismanto dan Basuki (2017), yang menunjukkan bahwa perlakuan dengan penambahan EBN (Ekstrak Buah Nanas) dan EBP (Ekstrak Buah Pepaya) pada pelumuran daging ayam parent stock afkir dengan persentase berbeda $(0,5,10$, dan 15 $\mathrm{ml} / 100$ gram daging) tidak menunjukkan perbedaan yang nyata terhadap nilai DIA daging ayam parent stock afkir. Selain itu, pada setiap perlakuan yang memberikan nilai hampir sama menunjukkan bahwa semua perlakuan diduga memiliki jumlah muatan positif dan negatif dalam daging yang hampir sama. Kesamaan jumlah kedua muatan ini akan menyebabkan penolakan dari miofilamen dan memberi ruang banyak pada molekul air sehingga DIA menjadi tinggi. Hal tersebut sesuai dengan pendapat Bouton et al. (1971) dan Wismer-Pedersen (1971), yang menyatakan bahwa pada $\mathrm{pH}$ yang lebih tinggi dari $\mathrm{pH}$ isoelektrik protein daging, sejumlah muatan positif dibebaskan dan terdapat surplus muatan negatif yang mengakibatkan penolakan dari miofilamen dan memberi lebih banyak ruang untuk molekul air.

Penggunaan sari buah pepaya muda terhadap daging paha itik petelur afkir tidak berpengaruh nyata terhadap DIA. Hal ini dapat disebabkan oleh adanya peristiwa osmosis yang terjadi kurang maksimal. Hal ini terlihat dari data bobot daging yang menunjukkan penurunan setelah perlakuan relatif sama. Menurut Kuntoro et al. (2007), osmosis merupakan pertukaran air antara sel dengan lingkungan karena perbedaan konsentrasi.

Penggunaan sari buah pepaya muda tidak berpengaruh nyata $(\mathrm{P}>0,05)$ terhadap DIA daging paha itik petelur afkir. Menurut Nelson dan Cox (2000), protease dari papain dapat meningkatkan keempukan karena protein jaringan ikat terhidrolisis dari enzim tersebut menjadi fragmen yang lebih pendek. Hidrolisis tersebut juga dapat meningkatkan daya ikat air, karena protein miofibril dapat bersifat sebagai basa kuat yang mengikat air. Hal ini menandakan bahwa semakin banyak papain yang masuk kedalam daging maka lebih banyak jaringan ikat yang terhidrolisis dan berdampak pada peningkatan protein miofibril yang bersifat basa kuat yang memiliki kemampuan mengikat air. Jika persentase pemberian sari buah pepaya muda ditingkatkan dimungkinkan mampu meningkatkan DIA daging itik pada penelitian.

\section{SIMPULAN DAN SARAN}

\author{
Simpulan \\ Marinasi sari buah pepaya muda $(0 \%$, \\ $10 \%, 20 \%$, dan 30\%) berpengaruh nyata \\ $(\mathrm{P}<0,05)$ terhadap peningkatan keempukan, \\ namun tidak berpengaruh nyata $(P>0,05)$ \\ terhadap nilai $\mathrm{pH}$ dan daya ikat air daging itik \\ petelur afkir. Marinasi sari buah pepaya muda \\ dengan persentase $30 \%$ merupakan dosis terbaik
}


diantara semua perlakuan untuk meningkatkan keempukan daging itik petelur afkir.

\section{Saran}

Disarankan untuk dilakukannya penelitian lebih lanjut mengenai marinasi daging itik petelur afkir dengan perbedaan tingkat kematangan buah pepaya yang digunakan dan peningkatan persentase pemberian sari buah pepaya saat marinasi, sehingga menghasilkan nilai $\mathrm{pH}$, daya ikat air, dan keempukan daging itik yang lebih baik.

\section{DAFTAR PUSTAKA}

Allen, C. D., D. L. Fletcher, J. K. Northcutt dan S. M. Russell. 1998. The relationship of broiler breast color to meat quality and shelf-life. Poultry Sci. 77:361--366.

Atmojo, Y. D., Obin, R., Roostita, B. 2016. Pengaruh penggunaan berbagai konsentrasi ekstrak lengkuas merah (Alpinia purpurata k. schum) terhadap daya awet daging ayam broiler. Jurnal. Universitas Padjadjaran. Sumedang.

Badan Pusat Statistika. 2019. Produksi daging itik/itik manila menurut provinsi, 20092019

https://www.bps.go.id/dynamictable/2015 /12/22\%2000:00:00/1066/produksidaging-itik-itik-manila-menurut-provinsi2009-2018.html. Diakses pada 3 Agustus 2020.

Bille, P.G. and M. S. Taapopi. 2008. Effects of two commercial meat tenderizers on different cuts of goat's meat in Namibia. African Journal of Food Agriculture Nutrition and Development, Vol.8, No.4, Dec, 2008, pp. 417--426. http://www.bioline.org.br/request?nd0803 8. Diakses pada 6 Desember 2019.

Bouton, P. E., P. V. Harris., and W. R. Shorthose. 1971. Effect of ultimate $\mathrm{pH}$ upon the water holding capacity and tenderness of mutton. J. Food Sci.36:435-439 .

Farid, A. M. 2015. Effectivity of papaya leaves (Carica papaya L) as inhibitor of aedes aegypti larvae. J Majority. 4(5):21--30.

Farida, D., H. D. Kusumaningrum, N. Wulandari, dan D. Indrasti. 2006. Analisa laboratorium. Departemen Ilmu dan Teknologi Pangan IPB. Bogor.

Fletcher, D. L . 2007. Poultry meat quality. World's Poultry Science Journal/Volume 58/Issue 02/June 2002, pp 131-145 http://journals.cambridge.org/action/displ
ayAbstract;jsessionid $=0 \mathrm{E} 2 \mathrm{CDF} 1 \mathrm{DB} 39 \mathrm{FE}$ A0DCB38572246F85082.journals?fromP age $=$ online \&aid $=622892$. Diakses pada 7 Desember 2019.

Ismanto, A. dan R. Basuki. 2017. Pemanfaatan ekstrak buah nanas dan ekstrak buah pepaya sebagai bahan pengempuk daging ayam parent stock afkir. Fakultas Pertanian, Universitas Mulawarman. Samarinda.

Kissel, C., L. S. Adriana., R. Alessandro., dan S. Massami., 2009. Funcctional properties of PSE (Pale, Soft, Exudative) broiler meet in the production of mortadella. Brazalian Archives of Biology and Technology an International Journal 52:35--43.

Kuntoro, B., I. Mirdhayati, T. Adelina. 2007. Penggunaan ekstrak daun katuk (Sauropus androgunus I. Men) sebagai bahan pengawet alami daging sapi segar. Jurnal Peternakan 4:6-12.

Lehninger, A.L. 1994. Principles of Biochemistry. Penerjemah: M. Thenawijaya. Penerbit Erlangga. Surabaya.

Lukman, H. 1995. Perbedaan karakteristik daging, karkas dan sifat olahannya antara itik afkir dan ayam petelur afkir. Tesis. Sekolah Pascasarjana Institut Pertanian Bogor, Bogor. 78 hlm.

Maulana, H. 2013. Beternak Itik Petelur. Penerbit Agro Media Pustaka.

Nelson, D. L., and M. M. Cox. 2000. Lehninger Principles of Biochemistry. $3^{\text {rd }}$ ed. Worth Pub., New York.

Soeparno. 2009. Ilmu dan Teknologi Daging. Edisi Ke-6. Gadjah Mada University Press. Yogyakarta.

Sunarlim, R. dan S. Usmiati. 2009. Karakteristik daging kambing dengan perendaman enzim papain. Seminar Nasional Teknologi Peternakan dan Veteriner 2009. Balai Besar Penelitian dan Pengembangan Pasca Panen Pertanian. Bogor.

Triyantini, 1983. Kandungan kimiawi daging ayam tua dengan penambahan larutan papain. Proseding Seminar Dies Natalis Fakultas Peternakan UGM ke-24, Yogyakarta.

Utami, D., Pudjomartatmo, \& A. Nuhriawangsa. 2011. Manfaat bromalin dari ekstrak buah nanas (Ananas comosus L. Merr) dan waktu pemasakan untuk meningkatkan kualitas daging itik afkir. Sains Peternakan. Vol.9(2): 82--87.

Wismer. and Pedersen, J. 1971. The Science of Meat and Meat Products. $2^{\text {nd }}$ Ed. J.F. 
Price and B.S, Schweigert, W. H. Freeman and Co., San Fransisco.

Young, J. F., Karlsson, A. H. \& Henckel, P. (2004). Water holding capacity in chicken breast muscle is enhanced by pyruvate and reduced by creatine sup-plements 1 . Poultry Sci. 83:400--405.

Yuwono, D. M. 2012. Budidaya Ternak itik petelur. Balai Pengkajian Teknologi Pertanian Jawa Tengah. 